\title{
DISTRIBUSI TEMPORAL DAN SPASIAL TEKANAN UDARA TERKAIT PERTUMBUHAN AWAN DI DAS LARONA, SULAWESI SELATAN
}

\author{
T.H.Seto
}

\begin{abstract}
Temporal and spatial data analysis of air pressure and rainfall data using AWS and rain gauges in the watershed of Larona, South Sulawesi has been done. From the results it appears that surface air pressure tends to fall when clouds develop. Pressure decreasing became energy which is used to draw air mass from the vicinity. When it rains then the air pressure increased due to the cooling of the air. From the spatial analysis it appears that areas with lower pressure tend to have higher rainfall than the surrounding areas. The results of this study can be used as a reference that when there is cloud growth in a location, air flow will go to the location of cloud growth. The stronger cloud's growth the stronger pull of the surrounding air mass. In weather modification technology, strengthen the growth of cloud technique may be used as one strategy to attract the mass of air or clouds of smaller clouds to the area with strong growth. But it still needs to do further research to prove this hypothesis.
\end{abstract}

\section{Intisari}

Telah dilakukan análisis temporal dan spasial data tekanan udara dan curah hujan menggunakan data hasil pengukuran dengan AWS dan penakar hujan manual di DAS Larona, Sulawesi Selatan. Dari hasil analisis temporal nampak bahwa tekanan udara permukaan cenderung turun saat pertumbuhan awan. Penurunan tekanan menjadi energi yang digunakan untuk menarik massa udara di sekitarnya. Ketika terjadi hujan maka tekanan udara menjadi tinggi akibat adanya pendinginan masa udara. Dari analisis spasial nampak bahwa daerah yang memiliki tekanan lebih rendah cenderung memiliki curah hujan yang lebih tinggi dibandingkan dengan daerah-daerah di sekitarnya. Hasil penelitian ini bisa dijadikan referensi bahwa ketika terjadi pertumbuhan awan di suatu lokasi maka aliran udara akan masuk menuju lokasi pertumbuhan awan. Semakin kuat pertumbuhan awannya maka semakin kuat tarikan massa udara dari sekitarnya. Dalam teknologi modifikasi cuaca, usaha memperkuat pertumbuhan awan mungkin bisa dijadikan salah satu strategi untuk menarik massa udara atau awan-awan yang lebih kecil ke area dengan pertumbuhan awan yang kuat. Namun masih perlu dilakukan penelitian lebih lanjut untuk membuktikan hipotesa ini.

\section{Kata kunci : Penurunan tekanan, pertumbuhan awan, peningkatan tekanan,} kejadian hujan.

\section{PENDAHULUAN}

Di ruang terbuka seperti atmosfir bumi yang merupakan sistem terbuka, segala kejadian yang terjadi di suatu wilayah akan saling terkait dan mempengaruhi dengan kejadian di wilayah lain. Pertumbuhan awan $\mathrm{Cb}$ di Indonesia juga tidak terlepas dari faktor cuaca global. Beberapa penelitian tentang faktor-faktor yang mempengaruhi pertumbuhan awan di wilayah Indonesia telah banyak dilakukan. Hadi dkk (2000, 2002) menyebutkan pengaruh angin laut terhadap

\footnotetext{
${ }^{1}$ Peneliti Madya - UPT Hujan Buatan, BPPT, Thamrin No. 8 Jakarta, email: thseto@yahoo.com
}

pertumbuhan awan di wilayah DKI. Variasi tahunan dari siklus harian angin dan aktifitas awan untuk wilayah Utara pulau Jawa juga telah diteliti oleh Araki (2006). Sedangkan intra seasonal variation yang banyak berpengaruh pada aktifitas koveksi di wilayah Indonesia telah diteliti oleh Seto dkk (2004, 2006). Analisis dengan model, Aldrian dkk (2003a,) dan Aldrian dan Susanto (2003b) menemukan bahwa hujan di wilayah Indonesia didominasi oleh hujan convective.

Proses cuaca di suatu wilayah akan mempengaruhi di wilayah yang berdekatan. Akan tetapi, proses cuaca yang cukup komplek cukup sulit untuk mengetahui seberapa besar 
pengaruhnya terhadap lingkungan sekitar, sehingga perlu dilakukan penelitian untuk mengetahui seberapa besar pengaruhnya terhadap wilayah di sekitarnya.

Perubahan tekanan permukaan merupakan salah satu faktor yang mempengaruhi pertumbuhan dan keberadaan awan di suatu daerah selain unsur uap air. Terkait dengan hal tersebut, fluktuasi tekanan udara permukaan yang diakibatkan oleh kejadian hujan sangat penting untuk dikaji. Atmosfer merupakan fluida dengan sistim yang terbuka dan tidak ada pembatas untuk mengisolasi bagian atmosfer supaya tidak saling berinteraksi. Dengan demikian, perubahan kondisi atmosfer di suatu lokasi akan mempengaruhi kondisi atmosfer di tempat lain.

Dalam tulisan ini dikaji perubahan tekanan permukaan di daerah pertumbuhan awan dan hujan, juga akan dibandingkan perubahan tekanan permukaan dengan lokasi sekitar kejadian hujan. Maksud dan tujuan dari penelitian ini adalah untuk mengetahui pergerakan udara di suatu wilayah dengan mempelajari pola distribusi spasial tekanan udara di wilayah tersebut. Dengan informasi ini maka dapat diprediksi lebih lanjut lokasi awanawan hujan yang akan tumbuh. Pola distribusi spasial tekanan udara ini sangat dibutuhkan untuk menentukan strategi penyemaian awan. Jika strategi penyemaian awan dapat dirancang dengan baik karena telah diketahuinya pola distribusi spatial tekanan udara ini, maka waktu dan lokasi penyemaian awan dapat ditentukan dengan tepat, sehingga dapat diperoleh hasil yang optimal.

\section{TINJAUAN PUSTAKA}

Tekanan udara adalah gaya yang disebabkan oleh berat satu kolom udara di atas satu luasan area. Di alam, perbedaan tekanan udara di permukaan bumi disebabkan oleh proses mekanik dan thermal. Proses mekanik merubah tekanan udara bila aliran udara tertahan sehingga terjadi penumpukan udara di lokasi tersebut dan mengakibatkan tekanan udara meningkat. Proses thermal diakibatkan oleh pemanasan atau pendinginan udara. Jika udara dipanaskan, udara akan naik dan akan menggeser lapisan udara di atasnya sehingga tekanan udara di permukaan akan turun. Sebaliknya, bila udara didinginkan, udara akan turun (subsidence) ke permukaan menyebabkan tekanan permukaan akan naik.

Perbedaan intensitas radiasi matahari terhadap permukaan bumi menyebabkan adanya temperature gradient. Wilayah yang relatif lebih hangat akan memiliki tekanan permukaan relatif lebih rendah dibandingkan dengan wilayah yang lebih rendah suhunya (lebih dingin). Perbedaan tekanan akan menimbulkan pressure gradient.
Pressure gradient menyebabkan aliran udara dari tekanan tinggi ke tekanan yang lebih rendah.

Sebagaimana dijelaskan di atas, tekanan rendah di permukaan mengindikasikan suhu udara lebih hangat. Tekanan rendah merupakan akibat adanya massa udara naik ke level yang lebih tinggi. Jika parcel massa udara lebih hangat dibanding suhu lingkungannya, parcel massa udara akan terus naik, dan tekanan di permukaan akan semakin turun. Hal ini akan terus berlangsung sampai parcel massa udara tidak mampu naik ke level yang lebih tinggi lagi. Sebagai ilustrasi, dapat dilihat pada Gambar 1.

Dari gambar 1 (kanan), tampak suhu parcel massa udara lebih rendah dibandingkan dengan suhu lingkungannya sehingga parcel massa udara tidak mampu untuk naik ke level yang lebih tinggi. Parcel massa udara akan turun, dan kondisi atmosfer seperti ini disebut kondisi stabil. Sebaliknya pada gambar 1 (kiri), parcel massa udara mampu naik ke level yang lebih tinggi karena suhu parcel massa udara lebih hangat dibandingkan suhu lingkungannya. Kondisi atmosfer seperti ini disebut tidak stabil. Awan cumulus (Cu) dapat tumbuh baik dalam kondisi atmosfer yang tidak stabil. Pertumbuhan awan $\mathrm{Cu}$ dapat mencapai awan cumulonimbus (Cb) apabila suplay massa udara cukup dan mengandung banyak uap air.
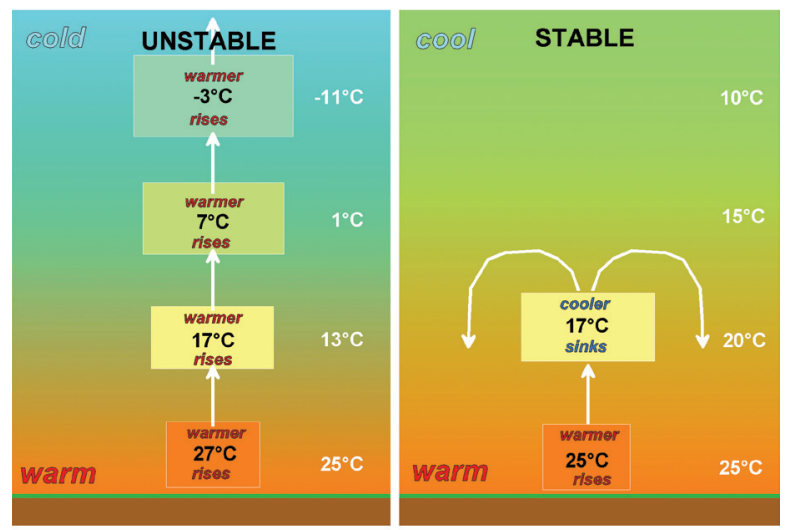

Gambar 1. Ilustrasi naiknya parsel massa udara ke level yang lebih tinggi pada kondisi atmosfer stabil (kanan) dan tidak stabil (kiri).

(Diambil dari http://epswww.unm.edu/ facstaff/gmeyer/envsc101/k11atmcompcirc. $\mathrm{htm})$

Proses parcel udara hangat naik ke level yang lebih tinggi akan berulang sampai suplay massa udara yang masuk tidak cukup membawa uap air dan kondisi atmosfer stabil. Pada kondisi ini akan sulit tumbuh awan Cu. Bila awan sudah mencapai fasa matang, hujan akan terjadi dan massa udara dalam bentuk hujan akan turun pada lokasi kejadian hujan. Tekanan udara pada 
permukaan akan berangsur naik pada lokasi hujan dibandingkan dengan besarnya tekanan permukaan sebelum terjadinya hujan.

Dari uraian di atas, dapat diimpulkan bahwa pada saat pertumbuhan awan tekanan permukaan akan berkurang dengan waktu sampai terjadi hujan. Pada saat kejadian hujan tekanan permukaan akan bertambah, sebagai akibat terjadinya sinking massa udara dalam bentuk hujan. Sebagaimana diketahui bahwa saat awan sudah dalam fasa matang, awan akan disipasi dan didominasi oleh gerakan ke bawah (downdraft).

Angin disebabkan oleh perbedaan tekanan udara di suatu wilayah dengan wilayah lain. Semakin besar beda tekanan udara maka semakin kuat pergerakan massa udara tersebut. Pada level boundary layer (biasanya kurang dari 500 $\mathrm{m}$ di atas permukaan tanah), angin bertiup dari tekanan tinggi ke tekanan rendah. Akibat putaran bumi menimbulkan adanya gaya coriolis yang membelokan arah angin. Pada level free atmosfer (di atas boundary layer), arah angin akan sejajar dengan isobar. Hal ini terjadi sebagai akibat adanya keseimbangan antara pressure gradient dan coriolis forces.

Untuk memahami pergerakan udara di suatu wilayah daerah aliran sungai (DAS) tertentu yang timbul akibat disipasi awan memerlukan data pengukuran parameter cuaca secara time series. Salah satu parameter yang bisa dilakukan analisis adalah angin permukaan. Pengamatan ini dilakukan dengan memasang alat pengukuran Automatic Weather Station (AWS) yang mana dilakukan juga pengukuran arah dan kecepatan angin permukaan.

\section{METODOLOGI}

\subsection{Lokasi}

Penelitian ini dilakukan di daerah aliran sungai (DAS) Larona, Propinsi Sulawesi Selatan. DAS Larona seluas 2500 km2 memilki danau kaskade (Danau Matano, Mahalona, dan Towuti) yang dimanfaatkan untuk keperluan PLTA. DAS ini mempunyai data pengamatan curah hujan yang panjang serta jaringan penakar yang cukup rapat baik penakar manual maupun penakar otomatis. Di DAS Larona telah terpasang jaringan penakar hujan manual dan jaringan AWS (Automatic Weather Station) sekitar 11 buah. Selain jaringan AWS, di lokasi penelitian juga terdapat radar cuaca yang sudah terpasang sejak tahun 2004 yang merupakan hasil kerja sama antara BPPT dengan PT. Inco.

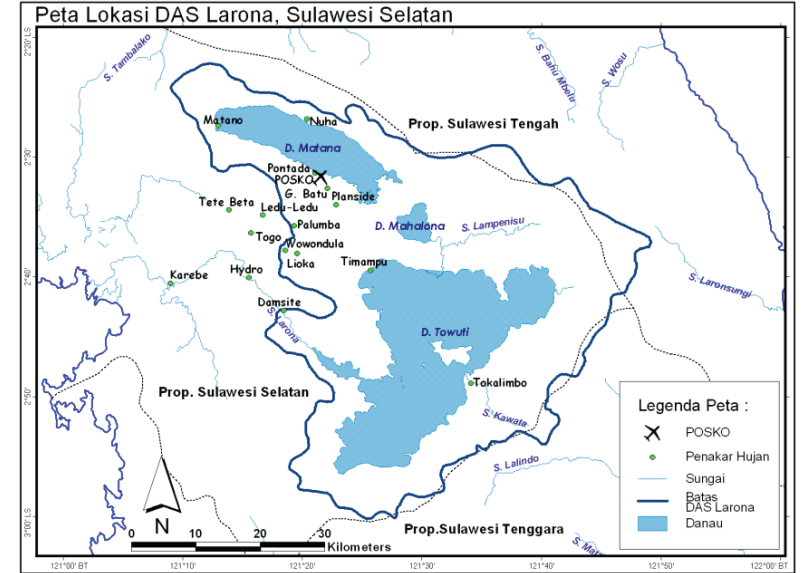

Gambar 2. DAS Larona Sulawesi Selatan.

\subsection{Data dan Metode}

Data yang akan digunakan adalah data tekanan udara permukaan dan curah hujan (yang diukur secara otomatis setiap 0,5 jam). Metoda yang dilakukan dalam penelitian ini adalah dengan menganalisis data AWS. Data hasil pengukuran AWS meliputi curah hujan, temperatur, kelembaban, tekanan udara, serta arah dan kecepatan angin. Pengamatan dengan AWS sifatnya kontinyu sehingga perubahan parameter cuaca dan hujan dapat diukur setiap saat dengan frekuensi pengukuran yang dapat di atur misalnya setiap 10 menit, 30 menit, 1 jam, dan sebagainya. Seluruh data diolah menggunakan metoda statistik sederhana, dengan menggunakan program fortran, GraDs, dan lain-lain.

Sementara itu, untuk melakukan analisis keterkaitan antara perubahan tekanan dan curah hujan dilakukan metode sebagai berikut:

1. Sortir data curah hujan harian yang mempunyai jumlah paling tinggi.

2. Hitung perubahan tekanan udara permukaan (delta tekanan) di setiap stasiun pengukuran pada hari di mana kejadian hujan memenuhi persyaratan di atas. Cara menghitung delta tekanan permukaan dengan cara mengurangkan besarnya tekanan pada jam tertentu dari besarnya tekanan sebelumnya, atau dapat digambarkan secara matematika sebagai: $\Delta \mathrm{p}=\mathrm{ph}-1-\mathrm{ph}$, dimana $\mathrm{p}$ adalah besarnya tekanan permukaan dan $h$ adalah jam (waktu).

3. Lihat fluktuasi delta tekanan pada saat sebelum, selama dan sesudah hujan.

4. Bandingkan fluktuasi tekanan permukaan di lokasi kejadian hujan dengan lokasi lainnya. Dengan menggunakan metode di atas maka 
data yang dipilih untuk dianalisis pada tulisan ini adalah data tanggal 16 Maret 2010, dimana terjadi hujan konvektif dengan jumlah curah hujan cukup tinggi.

\section{HASIL DAN PEMBAHASAN}

\subsection{Profil Tekanan}

Hasil analisis profil tekanan mulai jam 2.30 sore sampai dengan jam 11.30 malam (23:30) dapat dilihat pada Gambar 3. Dari gambar tersebut terlihat bahwa hampir semua stasiun mengikuti pola yang sama kecuali stasiun Bahudopi, hal ini dikarenakan stasiun Bahudopi terletak jauh di luar DAS Larona (di pantai Sulawesi Tengah) yang secara topografi berbeda dengan stasiun-stasiun di DAS Larona. Profil tekanan memperlihatkan mulai jam 17.00 LT tekanan naik secara gradual dan mencapai maksimumnya sekitar jam 21.30 LT. Stasiun yang dekat dengan permukaan air (Nuha, Balantang, Tokalimbo, Pomala) rata-rata mempunyai tekanan lebih rendah dibandingkan dengan stasiun yang berada jauh terhadap badan air.

Analisis tekanan udara terhadap curah hujan menunjukkan bahwa hujan umumnya terjadi

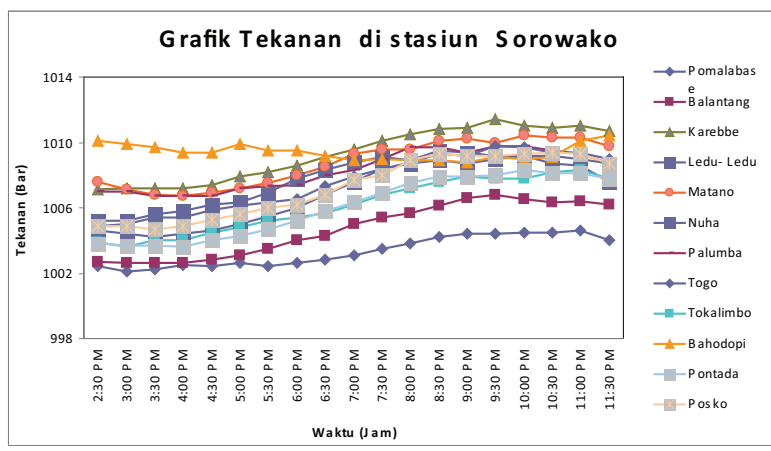

Gambar 3. Profil tekanan mulai jam 2.30 sore sampai dengan jam 11.30 malam (23:00) di DAS Larona

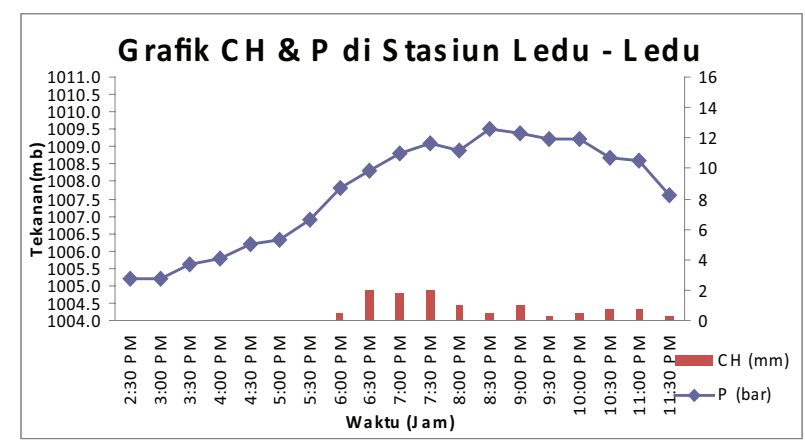

Gambar 4. Curah hujan dan tekanan di Stasiun Ledu-ledu pada sore hari antara jam 17.00 sampai dengan jam 20.00 LT. Dari hasil analisis intensitas curah hujan, stasiun-stasiun yang berada jauh dari badan air mempunyai intensitas curah hujan yang lebih rendah dibandingkan dengan stasiun-stasiun yang berada di dekat badan air.

Dari Gambar 4 sd. Gambar 6 menunjukkan bahwa proses pemanasan maksimum (ditunjukkan dengan nilai tekanan udara terendah dalam satu hari) dan proses pendinginan maksimum (ditandai dengan nilai tekanan udara tertinggi dalam satu hari) untuk stasiun dekat dengan badan air terjadi lebih awal dibandingkan dengan stasiun yang jauh dari badan air. Stasiun Leduledu yang mewakili daerah yang jauh dari badan air mengalami proses pemanasan maksimum pada sekitar jam 14.00LT dan proses pendinginan maksimum pada jam 21.00LT. Stasiun Matano dan Nuha yang mewakili daerah yang dekat dengan badan air memperlihatkan proses pemanasan maksimum terjadi sekitar jam 14.00LT dan proses pendinginan maksimum terjadi pada jam 23.00LT. Hal ini menyebabkan pertumbuhan perawanan di daerah dekat badan air (sekitar Danau) mengalami kelambatan dan hujan terjadi pada sore menjelang malam hari.

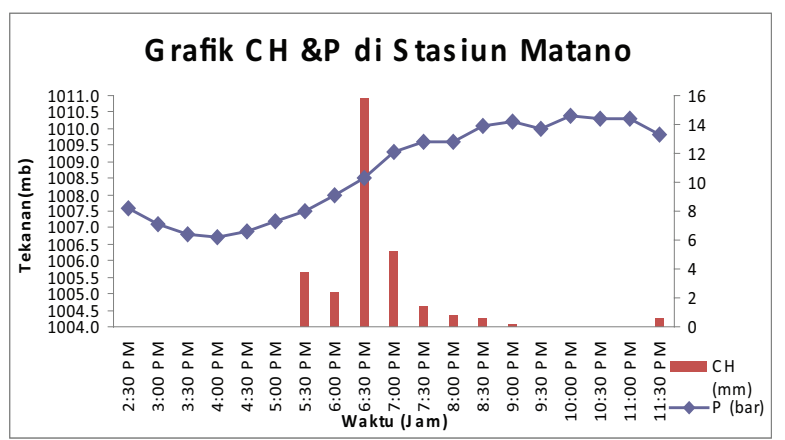

Gambar 5. Curah hujan dan tekanan di Stasiun Matano

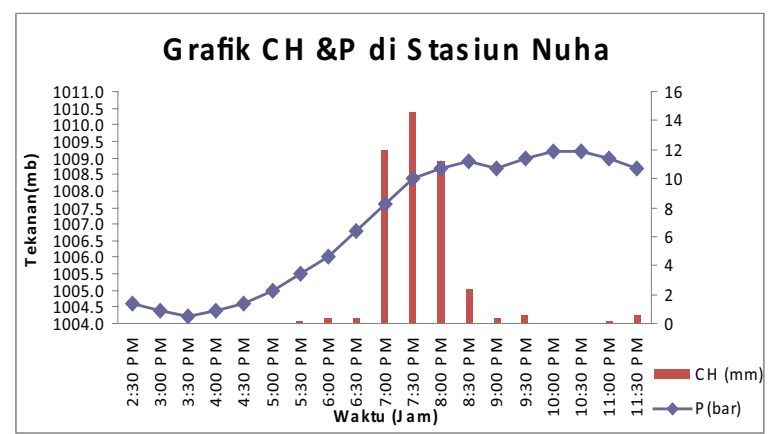

Gambar 6. Curah hujan dan tekanan di Stasiun Nuha. 
Dari hasil analisis tekanan udara menunjukkan bahwa proses dinamika atmosfer di sekitar badan air atau sekitar danau berlangsung lebih cepat dibandingkan dengan daerah yang jauh dari badan air. Karena perbedaan proses dinamika atmosfer tersebut menyebabkan intensitas hujan yang terjadi di daerah dekat badan air lebih besar dibandingkan dengan daerah yang berada jauh dari badan air.

\subsection{Tekanan Spasial}

Gambar 7 memperlihatkan peta spasial selisih tekanan udara permukaan di daerah pengamatan (1210 - 121.9 BT, -2.90 - (- 20) LS), tanggal 16 April 2008 jam 15:00 LT. Nilai selisih tekanan diperoleh dengan mengurangkan tekanan jam 14:30 LT dari tekanan jam 15:00 LT. Dari gambar tampak bahwa tekanan udara permukaan pada daerah masih dalam kondisi menurun yang ditandai dengan nilai negatif selisih tekanan. Pada saat itu, awan sedang tumbuh di daerah pengamatan.
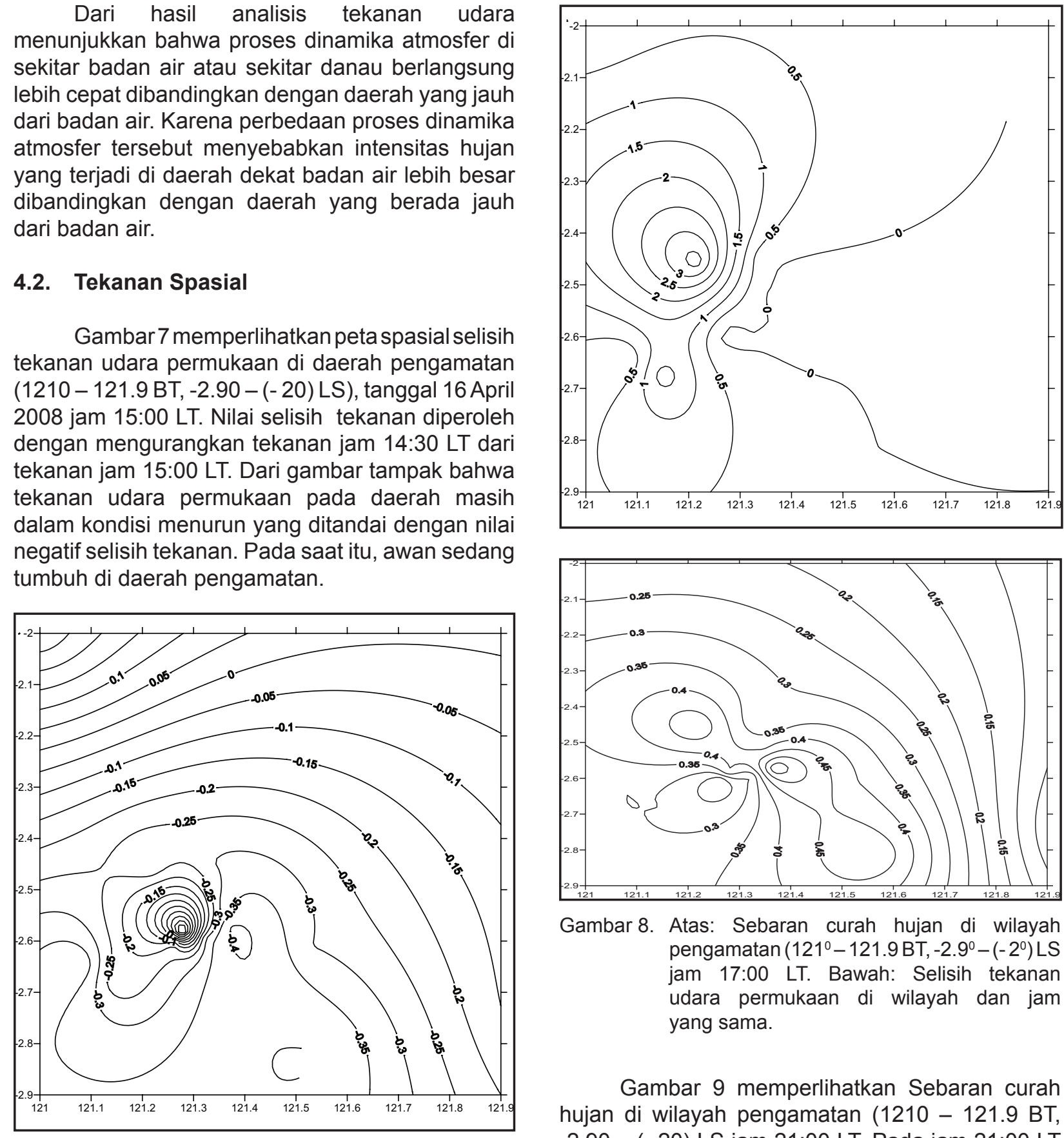

Gambar 8. Atas: Sebaran curah hujan di wilayah pengamatan $\left(121^{\circ}-121.9 \mathrm{BT},-2.9^{\circ}-\left(-2^{\circ}\right) \mathrm{LS}\right.$ jam 17:00 LT. Bawah: Selisih tekanan udara permukaan di wilayah dan jam yang sama.

Gambar 9 memperlihatkan Sebaran curah hujan di wilayah pengamatan (1210 - 121.9 BT, -2.90 - (- 20) LS jam 21:00 LT. Pada jam 21:00 LT hujan sudah mulai reda. Gambar 9 (bawah) adalah selisih tekanan udara pada daerah pengamatan yang sama. . Nilai delta tekanan diperoleh dengan mengurangkan tekanan jam 20:30 LT dari tekanan jam 21:00 LT. Dari gambar tampak bahwa tekanan udara permukaan sudah mulai menurun kembali dengan redanya hujan. Hal ini diindikasikan dengan nilai delta yang negatif.

Awan hujan, dalam hal ini awan cumulus (Cu), akan terbentuk apabila ada massa udara yang naik ke lapisan udara yang lebih tinggi sehingga terjadi kondensasi. Pengangkatan massa udara yang paling efektif dengan proses konveksi. Proses konveksi akan terjadi apabila suhu udara permukaan mencapai suhu konveksi, yang 

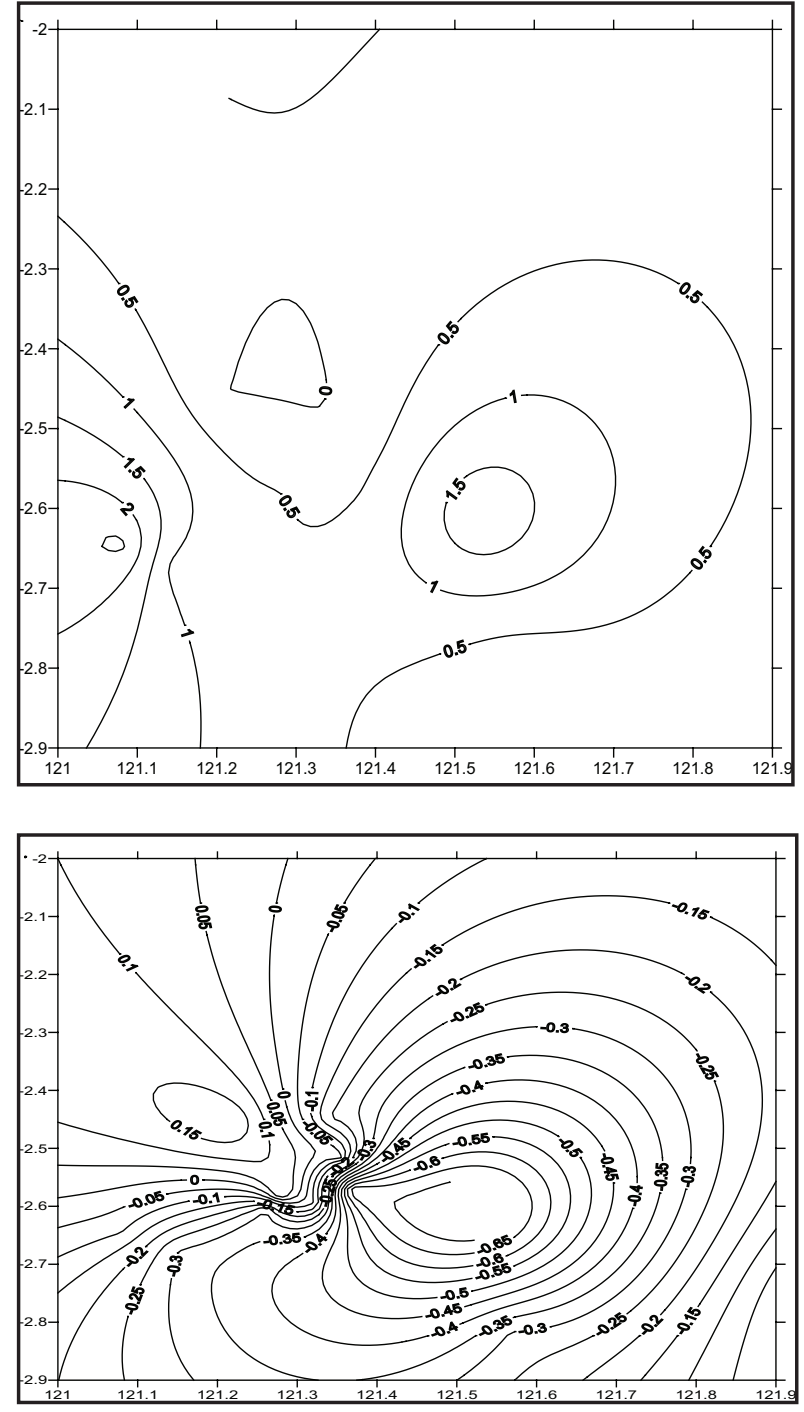

Gambar 9. Atas: Sebaran curah hujan di wilayah pengamatan $\left(121^{\circ}-121.9 \mathrm{BT},-2.9^{\circ}-\left(-2^{\circ}\right) \mathrm{LS}\right.$ jam 21:00 LT. Bawah: Delta tekanan udara permukaan di daerah dan jam yang sama.

biasanya membutuhkan radiasi matahari yang cukup kuat. Sebagai akibatnya, tekanan udara di permukaan akan berkurang. Kondisi ini akan terus berlangsung sampai terjadi turun hujan, di mana daerah pembentukan awan akan menjadi daerang sinking massa udara (bersamaan dengan down draft) dan butir air hujan.

Dengan turunnya hujan, tekanan udara permukaan di mana hujan turun berangsur akan naik akibat hilangnya gaya angkat (updraft) dan terjadinya sinking serta pendinginan udara permukaan. Kenaikan tekanan udara permukaan ini berlangsung sampai hujan reda, kemudian tekanan udara permukaan akan menjadi normal kembali bahkan ada kecenderungan mulai menurun, kecuali ada sistem tekanan yang menguat, baik tekanan udara rendah maupun tekanan udara tinggi yang akan mempengaruhi pola tekanan di stasiun pengamatan.

Hasil penelitian ini bisa dijadikan referensi bahwa ketika terjadi pertumbuhan awan di suatu lokasi maka aliran udara akan masuk menuju lokasi pertumbuhan awan. Semakin kuat pertumbuhan awannya maka semakin kuat tarikan massa udara dari sekitarnya. Dalam teknologi modifikasi cuaca, teknik memperkuat pertumbuhan awan mungkin bisa dijadikan salah satu strategi untuk menarik massa udara atau awan-awan yang lebih kecil ke area dengan pertumbuhan awan yang kuat. Namun masih perlu dilakukan penelitian lebih lanjut untuk membuktikan hipotesa ini.

\section{KESIMPULAN}

1. Tekanan udara di lokasi pertumbuhan awan mempunyai tendensi turun.

2. Saat hujan mulai turun, tekanan udara permukaan mulai naik akibat hilangnya gaya angkat (updraft) dan terjadinya sinking serta pendinginan udara permukaan.

3. Saat hujan mulai reda, tekanan udara permukaan mulai kembali normal dan berpeluang untuk turun kembali.

4. Dalam teknologi modifikasi cuaca, teknik memperkuat pertumbuhan awan mungkin bisa dijadikan salah satu strategi untuk menarik massa udara atau awan-awan yang lebih kecil ke area dengan pertumbuhan awan yang kuat. Namun masih perlu dilakukan penelitian lebih lanjut untuk membuktikan hipotesa ini.

\section{DAFTAR PUSTAKA}

Aldrian, E., L. D. Gates, and F. H. Widodo, 2003 a: Variability of Indonesian Rainfall and the Influence of ENSO and Resolution in ECHAM4 simulations and in the Reanalyses, MPI Report 346, 30pp [Available from Max Planck-Institut für Meteorologie, Bundesstr. 55, D-20146, Hamburg, Germany].

Aldrian, E. and R. D. Susanto, 2003b: Identification of three dominant rainfall regions within Indonesia and their relationship to sea surface temperature, International Journal of Climatology, 23, pp 1435-1452 DOI: 10.1002/joc.950.

Araki, R., M.D. Yamanaka, F. Murata, H. Hashiguchi, Y. Oku, T. Sribimawati, M. Kudsy, and F. Renggono, 2006: Seasonal and interannual variations of diurnal cycles of wind and cloud activity observed at Serpong, West Jawa, Indonesia, J. Meteor. Soc. Japan, 84A, pp 171-194. 
Hadi, T. W., T. Tsuda, H. Hashiguchi, and S. Fukao, 2000: Tropical Sea-breeze Circulation and Related Atmospheric Phenomena Observed with L-band Boundary Layer Radar in Indonesia, J. Meteor. Soc. Japan, Vol. 78, No. 2, pp. 123-140.

Hadi, T. W., Horinouchi, T. Tsuda, H. Hashiguchi, and S. Fukao, 2002: Sea-Breeze Circulation over Jakarta, Indonesia: A Climatology Based on Boundary Layer Radar Observations, Mo. Wea.Rev., 130, pp 21532166 DOI: 10.1175/1520-0493.

Seto, T.H., M. K. Yamamoto, H. Hashiguchi, and S. Fukao, 2004: Convective activities associated with intraseasonal variations over Sumatera, Indonesia, observed with the equatorial atmosphere radar, Ann Geophys, 22, pp 3899-3916.
Seto, T. H., M. K. Yamamoto, H. Hashiguchi, S. Fukao, M. Abo., T. Kozu., M. Kudsy, 2006: Observational Study on Westerly Wind Burst over Sumatra, Indonesia by the Equatorial Atmosphere Radar - A Case Study During the First CPEA Campaign -, J. Meteor. Soc. Japan, 84A, pp 95-112.

http://epswww.unm.edu/facstaff/gmeyer/envsc101/ wk11atmcompcirc.htm 
